RYSZARD STACHOWSKI ${ }^{1}$

Wyższa Szkoła Finansów i Zarządzania

$w$ Warszawie
Studia Psychologica

UKSW

16(1) 2016 s. 71-96

\title{
STEFAN BŁACHOWSKI WŚRÓD ZAWIERUCHY WIELKIEJ WOJNY
}

\author{
...ideał dalekiej przyszłości psychologii: \\ poznanie siebie samego i poznanie drugich. (...) \\ Ze zrozumienia siebie samego wyniknie wyrozumiałość dla drugich. \\ Stefan Błachowski, Czem jest i czem będzie psychologia? (1912)
}

\section{STRESZCZENIE}

Treścią artykułu jest życie i początek działalności naukowej Stefana Błachowskiego (1889-1962), ważnej postaci w historii polskiej psychologii w mrocznych latach Wielkiej Wojny, a także opis przeszkód, jakie musiał pokonać na drodze do doktoratu u Georga Müllera w Getyndze. Akademicką pracę naukową Błachowskiego dwukrotnie przerywał obowiązek służby wojskowej. Omówiona szczegółowo w artykule główna rozprawa naukowa Błachowskiego na temat nastawień i spostrzeżeń, choć napisana w niesprzyjających warunkach wojennych, nie straciła na aktualności.

Słowa kluczowe: historia polskiej psychologii, Stefan Błachowski, Wielka Wojna, ideał bliskiej przyszłości psychologii

\section{Stefan Beachowsin amid the turmoil of the Great War}

\begin{abstract}
This paper traces the life and the beginnings of the scientific career of Stefan Błachowski (1889-1962), a key figure in the history of Polish psychology, during the darkest days of the Great War. It outlines how and why the road to pursue his doctorate under the supervision of Georg Müller at Göttingen University was beset by many hurdles. The article also demonstrates how Błachowski's academic path was twice interrupted by military service and why his main work Nastawienia i spostrzeżenia (Sets and Perceptions), despite the fact that it came into being in all the vicissitudes of war, made a contribution of lasting value.
\end{abstract}

Keywords: Stefan Błachowski, the Great War, the history of Polish psychology, the ideal of the distant future of psychology

$1 \quad$ Adres do korespondencji: r.stachowski@vizja.pl. 


\section{WPROWADZENIE}

Stefan Walerian Błachowski ${ }^{2}$, urodzony 19 maja 1889 roku w Opawie (niem. Troppau), mieście leżącym nad rzeką Opawą na Śląsku Cieszyńskim w kraju morawsko-śląskim, w swoim 73-letnim życiu przeszedł polską drogę do niepodległości - był naocznym świadkiem dwóch wielkich wojen światowych. Drogę tę przeszedł w podwójnej roli: frontowego żołnierza i zakładnika wojennego oraz nauczyciela akademickiego i uczonego.

Kiedy 28 czerwca 1914 roku w Sarajewie padają strzały zapoczątkowujące Wielką Wojnę, ową Mickiewiczowską „wojnę powszechną za wolność ludów”, Stefan Błachowski wraz z nowo poślubioną żoną przebywa w Wiedniu. Ma wówczas 25 lat. Od ponad roku jest doktorem filozofii w zakresie psychologii, filozofii i fizyki, wypromowanym na Uniwersytecie w Getyndze. Od początku roku jest zatrudniony na Uniwersytecie Lwowskim. Trzynaście lat później, w roku 1927, ówczesny Dyrektor Departamentu Nauki i Szkół Wyższych Ministerstwa Wyznań Religijnych i Oświecenia Publicznego Stanisław Michalski (1865-1949) powie: „W Polsce w ogóle psychologów prawie nie ma [...] chyba jeden Błachowski" (Jadczak, 1997, s. 309)33.

2 Szerszy opis życia i działalności Stefana Błachowskiego patrz: Stachowski (2009), s. 9-42.

3 Józef Reutt (1907-1972), który w latach 1946-1954 pracował na Uniwersytecie Poznańskim w kierowanej przez Stefana Błachowskiego Katedrze Psychologii najpierw jako adiunkt, a następnie jako zastępca profesora (ten ostatni miał prawo wykładania, ale nie miał katedry; stanowisko to, wprowadzone w Polsce w roku 1951 na wzór systemu radzieckiego, zastąpiono po polskim Październiku ‘56 stopniem docenta), tak wspominał o swoim Profesorze: „Nieraz mi mówił, że w młodości otwierały się przed nim dwie drogi życia - życie uczonego i życie artysty. Z wielkimi bardzo wahaniami wybrał życie uczonego. Nie wiedział jednak, czy wybór ten był trafny. Latem 1961 roku, a więc już po zakończeniu swojej kariery naukowej raz jeszcze wrócił do tego tematu. I tak samo mówił: «Nie wiem, czy dobrze zrobiłem, wybierając drogę naukową»" (Reutt, 1962, s. 249). Wybrawszy drogę naukową, nie przechodził jednak obojętnie wobec wydarzeń politycznych w kraju. Znamiennym przykładem było jego zachowanie wobec dokonanego przez marszałka Józefa Piłsudskiego w dniach 12-15 maja 1926 roku w Warszawie zbrojnego zamachu stanu. „Metody sprawowania władzy przez ekipę sanacyjną” - pisze Jarosław Matysiak (2004, s. 160) - „połączone z szykanowaniem legalnej opozycji, a nawet uwięzieniem części posłów w więzieniu wojskowym w Brześciu nad Bugiem budziły głęboki niepokój i sprzeciw dużej części grona profesorskiego Uniwersytetu Poznańskiego, w tym i Stefana Błachowskiego. Dał temu wyraz, podpisując wraz z innymi profesorami UP list otwarty opublikowany 23 grudnia 1930 r. w «Kurierze Poznańskim», w którym czytamy: «Wstrząśnięci do głębi wiadomościami o więźniach brzeskich, które zostały podane $\mathrm{w}$ interpelacjach poselskich, solidaryzując się z profesorami UJ, zwracamy się do naszych kolegów Posłów i Senatorów z gorącym wezwaniem, by w imię honoru i dobra Polski, wszystkimi siłami dążyli do zupełnego wyświetlenia sprawy i pociągnięcia winnych do odpowiedzialności»". Taką postawą odszedł Błachowski od propagowanej przez jego Mistrza Kazimierza Twardowskiego w postępowaniu uczonego postawy nieinterwencji, charakteryzującej się „pewnymi formami uczestnictwa w życiu społecznym przy jednoczesnej niechęci do udziału w życiu politycznym" (Rzepa, 1993, s. 323). Owa postawa nieinterwencji, konsekwentnie zajmowana po II wojnie światowej przez uczniów Twardowskiego (na 
Dwadzieścia lat przed wybuchem II wojny światowej Błachowski powołuje do życia poznańską psychologię akademicką, dziewięć lat przed wojną redaguje założone przez siebie czasopismo naukowe „Kwartalnik Psychologiczny”, a sześć lat przed wojną organizuje Poznańskie Towarzystwo Psychologiczne. W dniu wybuchu wojny, 1 września 1939 roku, jeden „z najbardziej zasłużonych psychologów w Polsce, wybitny wychowawca kadr psychologicznych w kraju" (Hornowski, 1963, s. 7) ma już 51 lat i jest profesorem zwyczajnym psychologii. Już na początku wojny zostaje aresztowany jako zakładnik wojenny wraz grupą pracowników i studentów Uniwersytetu Poznańskiego i osadzony w poznańskim Ratuszu, a później w Collegium Marianum ${ }^{5}$. W listopadzie znajdzie się w obozie przejściowym na ul. Głównej w Poznaniu, po czym wraz z rodziną zostanie wyrzucony na bruk w Ostrowcu Kieleckim (Matysiak, 2004, s. 161; por. Stachowski, 2009, s. 27). Po powrocie do Poznania w marcu 1945 roku reaktywuje na Uniwersytecie Poznańskim Katedrę Psychologii, z którą będzie związany do końca roku akademickiego 1959/1960, czyli czasu, kiedy to zgodnie z ustawą przechodzi na emeryturę. Rok później wyjeżdża do córki do Warszawy, gdzie umiera ostatniego dnia stycznia 1962 roku.

\section{LATA GIMNAZJALNE WE LWOWIE (1899-1907)}

Spośród wyróżnionych przez Teresę Rzepę trzech okresów w dziejach psychologicznej Szkoły Lwowskiej (Rzepa, Dobroczyński, 2009, s. 154), założonej przez Kazimierza Twardowskiego (1866-1938), związana z tą szkołą życiowa droga Stefana Błachowskiego w czasach zawieruchy Wielkiej Wojny przypadła na

przykład Władysława Witwickiego), „przyniosła im prześladowania ze strony nie tylko władz politycznych PRL, lecz i ze strony osób ze świata nauki, potępiających «brak światopoglądu» w czasach tak «światopoglądowotwórczych»" (Rzepa, 1991, s. 48).

4 Wiosną 1939 roku wyszedł zeszyt 1. tomu XII „Kwartalnika Psychologicznego”, a latem został ukończony druk całego tomu. Ale „kiedy [10 września] Niemcy weszli do Poznania i rozpoczęli swą niszczycielską działalność [...] padł także ofiarą ich zbrodniczego szału XII-ty tom Kwartalnika Psychologicznego [...] zniszczono w Drukarni Uniwersytetu Poznańskiego cały nakład XII-tego tomu, z wyjątkiem zeszytu pierwszego, który ukazał się na wiosnę 1939 roku" (Błachowski, 1947, s. vii).

5 Collegium Marianum (Kolegium Maryjne) - zespół szkół prywatnych, obejmujący szkołę podstawową, gimnazjum i liceum. Siedziba zespołu mieściła się na ulicy Różanej 17 w Poznaniu, we wczesnomodernistycznym gmachu, zaprojektowanym w 1933 roku przez poznańskiego architekta Adolfa Pillera (1877-1951). Placówkę założył profesor Uniwersytetu Poznańskiego Jan Sajdak (1882-1967), twórca katedr filologii klasycznej na tym uniwersytecie, wkrótce po pozbawieniu go katedry w roku 1934 przez ministra Janusza Jędrzejewicza (1885-1951) w ramach tzw. reformy jędrzejewiczowskiej i posłaniu na niespodziewaną i przedwczesną emeryturę „za jego ludowe przekonania i podpisanie protestu przeciw znęcaniu się nad więźniami politycznymi w Brześciu i Berezie Kartuskiej” (Lewandowski, 2004, s. 87). 
drugą połowę drugiego okresu, obejmującego lata 1902-1919, oraz na początek okresu trzeciego (1920-1939).

Pierwszy krok na tej drodze wyznaczają lata szkolne Stefana Błachowskiego, których lapidarny opis przynosi jego własnoręczny życiorys: „Do szkoły powszechnej i średniej uczęszczałem we Lwowie. Po otrzymaniu w roku 1907 w V-ym gimnazjum we Lwowie świadectwa dojrzałości wstąpiłem na Wydział Filozoficzny Uniwersytetu Lwowskiego, w którym obok filozofii i psychologii studiowałem także polonistykę" ${ }^{\text {"6 }}$ Spróbujmy zatem z pomocą innych dostępnych źródeł historycznych zrekonstruować ten mało dotychczas znany okres w jego życiu.

U progu I wojny światowej istniało we Lwowie osiem męskich gimnazjów państwowych, z trzema filiami. Gimnazjum V wyodrębniło się z filii III Gimnazjum im. Franciszka Józefa z początkiem roku szkolnego 1892/1893 i za patrona przyjęło św. Jana Kantego. Według prawa obowiązującego w Monarchii Austro-Węgierskiej zgodę na utworzenie szkoły musiał wyrazić cesarz. W dniu 3 marca 1891 roku Franciszek Józef I (1830-1916) sygnował własnym podpisem tzw. postanowienie, które jednocześnie określało, że językiem wykładowym w szkole będzie język polski. Gimnazjum mieściło się w zabudowaniach klasztoru oo. Bernardynów na ul. Wałowej 18 . $Z$ powodu jego dynamicznego rozwoju musiano wynajmować $w$ kolejnych latach dwa piętra kamienicy na ul. Podwale 7, a w latach 1905-1907 na ul. Łyczakowskiej 1. W roku szkolnym 1896/1897 szkoła otrzymała klasę ósmą, dzięki czemu stała się pełnym gimnazjum. Po jego przeniesieniu w październiku 1907 roku do nowego budynku w dzielnicy Żółkiewskiej gimnazjum nadano imię Hetmana Stanisława Żółkiewskiego (Gajak-Toczek, 2010, 2011).

Do Lwowa młodego Błachowskiego przywiodła praca jego ojca Konstantego (1849-1921), który jako lekarz sztabu generalnego w garnizonach armii austro-węgierskiej był zmuszony często zmieniać miejsce zamieszkania rodziny: od Dębicy i Tarnopola po Opawę, Wiedeń i wreszcie Lwów. Kiedy po ukończeniu tutejszej czteroklasowej szkoły elementarnej i po zdaniu egzaminu wstępnego do Cesarsko-Królewskiego Gimnazjum V we Lwowie dziesięcioletni Stefan Błachowski rozpoczynał 3 września naukę w klasie IA, w gimnazjum było 16 oddziałów, z których osiem, obejmujących klasy od I do III, mieściło się w kamienicy na ulicy Podwale, pozostałe zaś klasy, od IV do VIII, zajmowały sale w budynku głównym, który stanowiły zabudowania klasztoru oo. Bernardynów na ulicy Wałowej (Sprawozdanie, 1900, s. 81). W roku szkolnym 1906/1907, kiedy Błachowski był już uczniem klasy maturalnej VIIIA, uczył się w budynku głównym na ulicy Wałowej 18. W pierwszym tygodniu maja 1907 roku odbyła się wycieczka szkolna do Wiednia, jednak nie wiemy, czy Błachowski w niej uczestniczył. Wiemy natomiast, że udzielał się w kółku naukowym czytelni

6 Archiwum Uniwersytetu im. Adama Mickiewicza w Poznaniu, sygn. 15/170. 
młodzieżowej, która została założona w szkole w drugim półroczu 1906/1907 i mieściła się w budynku głównym Gimnazjum. W lokalu tej czytelni wygłosił dwa odczyty: Stosunek Słowackiego do Mickiewicza i Kilka słów o idei Nieboskiej komedyi (Sprawozdanie..., 1907, s. 75). W latach, gdy chodził do Gimnazjum, odbywały się w nim różne uroczystości szkolne, jak na przykład z okazji rocznicy powstania listopadowego, na których śpiewano pieśni religijno-patriotyczne i słuchano przemówień nauczycieli historii na temat znaczenia rocznicy, czy dla uczczenia narodowych wieszczów, a także osobno ku czci Juliusza Słowackiego i Adama Mickiewicza oraz inne. Młodzież uczestniczyła także w systematycznych uroczystościach szkolnych z okazji imienin Najjaśniejszego Cesarza Franciszka Józefa I. Początkowi i zakończeniu każdego roku szkolnego towarzyszyło uroczyste nabożeństwo - dla uczniów obrządku rzymskokatolickiego zazwyczaj w kościele oo. Bernardynów, a dla obrządku greckokatolickiego, w cerkwi Wołoskiej. Młodzież uczestniczyła także regularnie w rekolekcjach wielkopostnych i okresowych spowiedziach ${ }^{7}$. Podczas uroczystości bierzmowania klas III-V w roku 1907 biskup Władysław Bandurski (1865-1932), słynący z patriotycznych kazań duchowy pasterz Legionów, przemawiał „gorącemi i podniosłemi słowy, zachęcając ich do pracy i gorliwości w służbie Bogu i Ojczyźnie” (Sprawozdanie..., 1907, s. 69). Pisemny egzamin dojrzałości, który obejmował języki: polski („Znaczenie wieku XVII w historii literatury narodowej”), łaciński, grecki i niemiecki oraz matematykę, odbywał się w dniach od 13 do 17 maja 1907 roku, egzamin ustny natomiast - od 10 do 20 czerwca (Sprawozdanie..., 1907, s. 69). Rok szkolny 1906/1907 zakończył się 6 lipca uroczystym nabożeństwem i rozdaniem świadectw.

\section{LATA UNIWERSYTECKIE WE LWOWIE, WIEDNIU I GETYNDZE (1907-1913)}

Świadectwo dojrzałości otwierało drogę do uniwersytetu, na który osiemnastoletni Stefan Błachowski zapisuje się jeszcze w tym samym roku. Uniwersytet Lwowski był w tym czasie czwartym najstarszym założonym na ziemiach Rzeczypospolitej Korony Polskiej i Wielkiego Księstwa Litewskiego uniwersytetem, w którym można było studiować filozofię z psychologią i przyrodoznawstwo. Był on zarazem największym na przełomie wieków XIX i XX uniwersytetem w Galicji i drugim w Austrii, po Uniwersytecie Wiedeńskim, założonym w roku 1365 przez Rudolfa IV, księcia Austrii z dynastii Habsburgów.

Tadeusz Zaworski (1907-2007), jeden z uczniów Stefana Błachowskiego, przytacza pewne zdarzenie z życia religijnego Stefana Błachowskiego: „ostatnie, jakie z życia profesora znam nie $\mathrm{z}$ osobistego doświadczenia wprawdzie, ale z relacji osób trzecich, niemniej wszakże wiarygodne. Gdy leżał ciężko chory, już bez nadziei na wyzdrowienie, ktoś z najbliższego jego otoczenia zapytał go, czy zgodziłby się przyjąć księdza, odpowiedział: «Nigdy z Bogiem nie walczyłem». Przyjęto to jako wyrażenie zgody” (Zaworski, 1994, s. 8). 
W okresie zaboru austriackiego nosił nazwę C.K. Uniwersytet im. Cesarza Franciszka I i stąd potocznie zwany był Franciszkańskim. Założony przez króla Polski Jana Kazimierza w roku 1661 jako Akademia Lwowska, wyłonił się z założonego pod koniec XVI wieku i rozszerzonego w roku 1608 Kolegium Jezuickiego. Od 22 listopada 1919 roku nosił nazwę Uniwersytet Jana Kazimierza, od nazwiska założyciela.

Katedrą filozofii od roku 1895 kierował Kazimierz Twardowski (1866-1938), trzy lata później profesor zwyczajny filozofii, który w semestrze zimowym 1898/1899 rozpoczął wykłady z psychologii eksperymentalnej, a w roku 1907 otworzył oficjalnie pracownię psychologiczną ${ }^{8}$ (por. Rzepa, 1992). „Spotkanie z Twardowskim zaowocowało później skłonnością do podejmowania badań nad problemami podstawowymi, wymagającymi dyskusji i polemiki z wybitnymi uczonymi Europy" (Matysiak, 2004, s. 157). Przez trzy semestry Błachowski słuchał wykładów swojego nauczyciela i Mistrza - jak się później wyrazi o Kazimierzu Twardowskim - i brał udział w prowadzonych przez niego ćwiczeniach z psychologii, po czym dla uzupełnienia studiów wyjechał na jeden semestr do Wiednia9.

O pobycie Błachowskiego w Wiedniu wiemy niewiele poza tym, co sam zdawkowo napisał w swoim życiorysie: „po krótkim pobycie w Uniwersytecie Wiedeńskim, przeniosłem się jesienią 1909 do Getyngi, gdzie rozszerzyłem zakres moich studiów na nauki biologiczne i fizykę". Do Wiednia wróci jeszcze raz, na rok przed wybuchem I wojny światowej, „po uzyskaniu z początkiem r. 1913 w Uniwersytecie Getyngeńskim ${ }^{10}$ stopnia doktora filozofii (w zakresie

8 W czasie gdy Stefan Błachowski uczył się w V Gimnazjum we Lwowie, Kazimierz Twardowski gościł w nim dwukrotnie. Za pierwszym razem, w roku 1902, w dniach od 20 czerwca do 4 lipca przewodniczył komisji egzaminacyjnej podczas ustnego egzaminu dojrzałości (Sprawozdanie..., 1902, s. 70). Drugi raz, jako delegat Senatu Uniwersytetu Lwowskiego, był obecny 31 października 1904 roku na uzupełniającym ustnym egzaminie dojrzałości jednego z abiturientów szkoły realnej (Sprawozdanie..., 1905, s. 70-71).

9 W najwcześniejszym z zachowanych życiorysów, którego niemiecki oryginał Czesław Głombik (1999, s. 83) znalazł w archiwum Uniwersytetu w Getyndze, 23 stycznia 1913 roku Stefan Błachowski napisał, że po otrzymaniu świadectwa dojrzałości poświęcił się „,uniwersyteckim studiom filozoficznym i przyrodoznawczym wpierw we Lwowie (trzy semestry), następnie w Wiedniu (jeden semestr) i - od Michała [wrzesień] 1909 - w Getyndze”. Inne znane mi zachowane życiorysy (dwa w Archiwum Uniwersytetu im. Adama Mickiewicza w Poznaniu i jeden w Archiwum Polskiej Akademii Nauk w Warszawie Oddział w Poznaniu) pochodzą z lat 1950 i 1954.

10 Uniwersytet w Getyndze (Georg-August-Universität Göttingen), zwany Georgiana, został ufundowany w roku 1734 przez lokalnego władcę Georga Augusta, elektora hanowerskiego, który jako George II był jednocześnie królem Wielkiej Brytanii. Na Kongresie Wiedeńskim elektorat hanowerski został podniesiony do rangi królestwa, które po wojnie prusko-austriackiej zostało w roku 1866 anektowane przez Prusy. Ten kontekst polityczny w dużym stopniu kształtował osobliwą atmosferę Uniwersytetu, przyciągającą do Getyngi 
psychologii, filozofii i fizyki)" - jak czytamy w życiorysie - żeby kontynuować „studia przyrodnicze w ciągu letniego semestru 1913 r.”. Aczkolwiek jedyny znany mi dokument $z$ tego okresu nosi datę niejednoznaczną. Na wewnętrznej stronie okładki indeksu w formie książeczki (Meldungsbuch) Stefana Błachowskiego ${ }^{11}$ (przechowywanego w Archiwum Polskiej Akademii Nauk w Warszawie Oddział w Poznaniu) widnieje zdjęcie właściciela i pod nim jego własnoręczny podpis. Jednak w miejscu do tego przeznaczonym pod podpisem nie ma daty. Pojawia się ona dopiero na następnej stronie indeksu, którą otwiera jego numer: 49592. Pod nim ręką Błachowskiego napisane są imię i nazwisko oraz niemiecka nazwa miejsca urodzenia: Troppau. Niżej, w odpowiednim miejscu Błachowski wpisał philosophischen jako nazwę wydziału k. k. Universität zu Wien, na który został przyjęty. I teraz u dołu strony pojawia się wspomniana wyżej kontrowersyjna data, a właściwie: dwie daty, dopisane ołówkiem, wskazujące na rok akademicki. Wyraźnie widać, że data 1914/1915 została napisana na dacie 1913/1914, jednak w taki sposób, że nie zasłania jej całkowicie, co świadczy o tym, że została dopisana później.

Z indeksu możemy się dowiedzieć, że w ciągu dwóch semestrów Błachowski zaliczył następujące przedmioty: $w$ semestrze pierwszym (chodzi zapewne o rok 1909 i pierwszy wyjazd do Wiednia): chemię u prof. Goldschmiedla (część I, 5 godzin), mineralogię ogólną u prof. Becke’a (5 godzin), ćwiczenia z krystalografii i mineralogii, też u Becke’a (4 godziny), oraz psychologię u prof. Aloisa Höflera (4 godziny) ${ }^{12}$; w semestrze drugim (zapewne w roku 1913): mineralogię specjalną u Becke’a (5 godzin), chemię u Goldschmiedla (część II, 5 godzin), ćwiczenia $\mathrm{z}$ dmuchawką lutowniczą u prof. Doeltera (4 godziny) oraz anatomię zwierząt dla początkujących u prof. prof. Grobbena i Wernera (3 godziny). W następnym semestrze natomiast Błachowski musiał już nie uczestniczyć w zajęciach, skoro trzy wpisane przez niego przedmioty (po polsku, a nie, jak w obydwu poprzednich semestrach, po niemiecku): zoologia, embriologia porównawcza i botanika szczegółowa nie są potwierdzone podpisami ani wykładowców, ani dziekana. Być może był to plan studiów w semestrze w roku akademickim 1914/1915, do których nie doszło. Można zatem przyjąć, że wpisy i pieczątki w indeksie jednoznacznie poświadczają oba pobyty Stefana Błachowskiego na Uniwersytecie Wiedeńskim, o których wspomina w swoim życiorysie. Do wyjaśnienia natomiast w przyszłości pozostaje wspomniana kontrowersyjność dat.

tych studentów, którzy z różnych powodów byli Prusom niechętni (por. Lück, 2008, s. 256, przyp. 32. W. Zeidlera).

11 Nr zespołu 83/0, k. B. Za umożliwienie mi wglądu do indeksu i pomocny komentarz dziękuję dr. Jarosławowi Matysiakowi z Archiwum Polskiej Akademii Nauk w Warszawie Oddział w Poznaniu.

12 W latach gimnazjalnych Stefana Błachowskiego w bibliotece szkolnej znajdowała się książka Aloisa Höflera (1853-1922) z roku 1897: Psychologie. Ten austriacki filozof w roku 1899 wygłosił pierwszy na Uniwersytecie Wiedeńskim wykład z psychologii eksperymentalnej. 
Drugim dokumentem, również ze zbiorów Archiwum PAN w Warszawie Oddział w Poznaniu, jest tymczasowe zaświadczenie (Provisorischer Aufnahmschein) o immatrykulacji Stefana Błachowskiego na Wydział Filozoficzny Uniwersytetu Wiedeńskiego, z datą 26 stycznia 1915 roku i podpisem dziekana. Nie wiadomo, komu i w jakim celu zostało wystawione to zaświadczenie. Zastanawia również data na pieczęci na dokumencie: „27 Januar 1916”, co sugerowałoby, że pismo zostało Błachowskiemu w tym czasie albo doręczone, albo wysłane po roku od jego wystawienia! Jedno wiemy na pewno: był to już czas Wielkiej Wojny.

Zajrzyjmy ponownie do życiorysu ${ }^{13}$. „W czasie pierwszej wojny światowej” - pisze Błachowski - „zostałem w r. 1915 wcielony do armii austriackiej jako szeregowiec 30-go (lwowskiego) pułku piechoty, skąd zostałem na zasadzie reklamacji Uniwersytetu Lwowskiego zwolniony w styczniu 1916 r.”. Zrekonstruujmy te wydarzenia. W dniu wybuchu Wielkiej Wojny, 28 czerwca 1914 roku, oddziały 30. Lwowskiego Pułku Piechoty stacjonują w Bośni i dlatego od razu przystępują do walki. 6 sierpnia 1914 roku Austro-Węgry wypowiadają wojnę Rosji. Następnie Rosjanie, po początkowej klęsce swoich wojsk w bitwach pod Kraśnikiem i Komarowem, rozpoczynają główną ofensywę, uderzając ze wschodu w kierunku Lwowa, żeby po złamaniu oporu wojsk austro-węgierskich 3 września wkroczyć do miasta. W następnym roku, 22 czerwca po południu, po dziewięciu miesiącach do Lwowa ponownie wkraczają pierwsze oddziały armii austriackiej ${ }^{14}$. Warto przy tym zauważyć, że w armii austriackiej służyło około 1,4 miliona Polaków.

W liście, który Stefan Błachowski napisał 5 września 1914 roku (dwa dni po zajęciu Lwowa przez Rosjan) z Wiednia do przebywającego w Poroninie Kazimierza Twardowskiego, donosi1 ${ }^{15}$ :

Wielce Szanowny Panie Profesorze! Nie otrzymawszy odpowiedzi na moją przed paru tygodniami pisaną kartkę, w obawie, że Szanowny Pan Profesor znajduje się w zagrożonym Lwowie, udałem się wczoraj do Brata Pana Profesora i dowiedziałem się, że Szanowny Pan Profesor spędza

13 Archiwum Uniwersytetu im. Adama Mickiewicza w Poznaniu, sygn. 15/170.

14 Józef Białynia Chołodecki (1852-1934) tak wspominał ten dzień: „Zawitał dzień 22 czerwca r. 1915, dzień osnuty w dymy nocnych pożarów, ale pogodny i pełen błogich nadziei wśród strapionej ludności. Około godziny 9 rano podążył w towarzystwie kozaka oficer rosyjski na wieżę ratuszową, zdjął chorągiew o barwach rosyjskich, zwinął ją i odszedł w milczeniu, a równocześnie znikły chorągwie z drzewca na Kopcu Unii Lubelskiej i na gmachu Namiestnictwa. 293 dni trwające rządy rosyjskie we Lwowie zakończyły się" (Białynia Chołodecki, 1930, s. 167-168).

15 Cytowane tutaj listy od Stefana Błachowskiego do Kazimierza Twardowskiego pochodzą $\mathrm{z}$ archiwum Kazimierza Twardowskiego w Bibliotece Instytutu Filozofii i Socjologii Polskiej Akademii Nauk w Warszawie (sygnatura: Rkps 02.1.T.IV, k. 4-307). Pisownia oraz interpunkcja oryginalne. 
wakacye w dalszym ciągu w Poroninie i że się Panu Profesorowi oraz Jego Rodzinie dobrze wiedzie. Ja od 4. sierpnia bawię z żoną ${ }^{16}$ we Wiedniu w ciągłej trosce o Lwów.

Sam Twardowski tak wspominał po latach tamten pamiętny wyjazd na wakacje:

Dziś [17 września] cztery lata temu wyruszyłem z Żoną, dziećmi i kucharką z Poronina do Wiednia, aby tam - w myśl jednomyślnej uchwały kolegów zebranych kilka dni przedtem w mieszkaniu Antoniewicza w Sienkiewiczówce w Zakopanem - strzec interesów Uniwersytetu Lwowskiego w siedzibie władzy centralnej - jako wybrany i zatwierdzony na rok 1914/1915 Rektor ${ }^{17}$. (Jadczak, 1997, s. 59; por. Jadczak, 1990, s. 427)

Jak pisze Ryszard Jadczak:

Wypadki wojenne, zajęcie Lwowa i częściowa ewakuacja Krakowa sprowadziły do Wiednia znaczną liczbę młodzieży, w części od samego początku niezdolną do noszenia broni, ale także z Legionów lub właśnie zwolnioną z wojska. Wszystkich tych, którzy pragnęli kontynuować przerwane studia, K. Twardowski skupił wokół siebie, organizował i otoczył opieką. (1990, s. 429)

Jednak Twardowski przede wszystkim „w porozumieniu z władzami ułatwiał studentom dostęp i wpisy do Uniwersytetu Wiedeńskiego" (Jadczak, 1990, s. 429). Dlaczegoż by nie miał z tego skorzystać i przebywający w tym czasie w Wiedniu Stefan Błachowski? Jeżeli rzeczywiście tak było, to mielibyśmy wyjaśnienie sytuacji, w której doszło do napisania przez Błachowskiego w indeksie wspomnianej wcześniej daty 1914/1915 na dacie 1913/1914.

Tymczasem 12 sierpnia 1914 roku we Lwowie Senat Uniwersytetu Lwowskiego wydaje odezwę sygnowaną podpisem pełniącego obowiązki rektora prof. Stanisława Starzyńskiego (1853-1935), w której to odezwie nawołuje młodzież akademicką do „solidarności narodowej, jedności myśli działania, jako do elementarnych przykazań miłości ojczyzny” (Białynia Chołodecki, 1930, s. 15). „Największym na dziś obowiązkiem” - brzmiała dalsza treść odezwy - „jest iść

16 Stefan Błachowski i Maria z domu Elbracht-Hülseweh (ur. 14 czerwca 1887 w Sende w Westfalii, zm. 19 grudnia 1969 w Warszawie) połączyli się ślubem 23 kwietnia 1914 roku we Lwowie.

W czerwcu 1914 roku Uniwersytet Lwowski powierzył Twardowskiemu urząd rektora na kolejny rok akademicki 1914/1915, który ten objął zgodnie ze zwyczajem akademickim 23 września w Wiedniu po przyjeździe z Poronina, kiedy z powodu zajęcia Lwowa przez Rosjan powrót do domu stał się niemożliwy. Do Lwowa wróci 5 lipca następnego roku. Normalna działalność Uniwersytetu Lwowskiego, która skutkiem wojny niemal zupełnie ustała na okres jednego roku akademickiego, we wrześniu 1915 roku zostaje wznowiona cyklem powszechnych wykładów akademickich z zakresu higieny i epidemiologii (por. Jadczak, 1990). 
na pole walki, z bronią w ręku, spełnić powinność i stwierdzić czynem, że na szalę wydarzeń rzucamy nie tylko to, co wypływa z obowiązku wobec państwa, ale i to, cośmy sami winni sławnej naszej przeszłości narodowej” (Białynia Chołodecki, 1930, s. 15). Na koniec odezwy senat apeluje do tych słuchaczy wszechnicy, „którym warunki fizycznej natury nie pozwalają dzierżenia oręża w dłoni”:

Bierzmy się do pracy, każdy w miejscu swojego stałego zamieszkania, imajmy się pracy, zarówno trudniejszej jak i łatwiejszej. Zgłaszajmy się do zastępstw w opustoszałīch biurach, do pracy na roli, w przemyśle, do opieki nad rannymi, która w szczególności jest tak pięknem zadaniem dla naszych słuchaczek; idźmy wszędzie, gdzie jest praca i dawajmy przykład pracy. (Białynia Chołodecki, 1930, s. 15-16)

Choć w Wiedniu jest wówczas spokojnie, to w Europie wojna zatacza coraz szersze kręgi. W dniu, w którym nowożeńcy Błachowscy przyjeżdżają do stolicy Austrii, Niemcy wypowiadają wojnę Belgii, a Wielka Brytania - Niemcom. W tym czasie w życiu Stefana oprócz małżeństwa zachodzi jeszcze jedna ważna zmiana: od października 1913 roku, a więc po zakończeniu semestru letniego na Uniwersytecie Wiedeńskim i po uzyskaniu przed siedmioma miesiącami doktoratu na Uniwersytecie w Getyndze ${ }^{18}$, otrzymuje on angaż na stanowisko asystenta-wolontariusza na Uniwersytecie Lwowskim, na seminarium

18 Na studia w Getyndze Błachowski przyjechał pod koniec września („na Michała”) 1909 roku. Swoje "getyngeńskie wygnanie” trwające prawie trzy i pół roku - jak się wyrazi w liście do Twardowskiego 12 września 1912 roku -zwieńczył doktoratem, który uzyskał 5 marca 1913 roku na podstawie rozprawy zatytułowanej Studien über den Binnenkontrast (Badania nad kontrastem wewnętrznym). Promotorem był Georg Elias Müller (1850-1934), jeden z ojców-założycieli psychologii eksperymentalnej w Niemczech, do którego - jak to wiele lat później Błachowski napisze w liście do Kazimierza Twardowskiego z datą 14 stycznia 1935 roku - „był bardzo przywiązany i którego wysoko cenił jako uczonego i człowieka o najwyższych walorach. Pracował naukowo do końca życia. Jeszcze kilka tygodni przed śmiercią nadesłał [...] parę najświeższych swych publikacji. Do „Kwartalnika Psychologicznego” był bardzo życzliwie usposobiony, obiecał nawet współpracę, ale nie zdążył swej obietnicy zrealizować" (por. Błachowski, 1935). Müller brał udział w wojnie francusko-pruskiej w latach 1870-1871 jako ochotnik w armii niemieckiej. Na czas "getyngeńskiego wygnania”, uwieńczonego doktoratem u Georga Müllera, przypadły pierwsze kroki Błachowskiego $\mathrm{w}$ bogatym dorobku publikacyjnym $\mathrm{w}$ czasopismach polskich o zasięgu europejskim (np. „Przegląd Filozoficzny”, „Ruch Filozoficzny”) i niemieckich (np. „Zeitschrift für Psychologie und Physiologie der Sinnesorgane“, „Zeitschrift für wisseschaftliche Instrumentenkunde“), niezrealizowany młodzieńczy pomysł założenia czasopisma naukowego poświęconego zagadnieniom kultury polskiej oraz zaangażowanie w działalność międzynarodowego związku studenckiego (Verband der Internationalen Studenten-Vereine an deutschen Hochschulen), wynikające z jego przekonania o potrzebie obecności Polaków w zorganizowanym ruchu studenckim. Szerszy opis drogi Błachowskiego do doktoratu oraz jego działalności organizatorskiej patrz: Stachowski, 2009 (por. Głombik, 1999). 
psychologicznym Kazimierza Twardowskiego, po czym od 1 stycznia 1914 roku przechodzi na etat starszego asystenta $\mathrm{w}$ kierowanym przez Twardowskiego Zakładzie Psychologii i na seminarium filozoficznym. Na tym stanowisku pozostanie do 1 lutego 1918 roku, angaż ten obejmuje zatem okres I wojny światowej.

Mimo że zasadnicze studia, odbywane na polskim uniwersytecie, Stefan Błachowski uzupełniał na uniwersytetach austriackim i niemieckim, a na uniwersytecie niemieckim jeszcze się doktoryzował, to jednak po wstąpieniu na drogę naukową ucieleśnieniem jego marzeń miała być praca w polskim ośrodku naukowym. Myśl o pracy u boku Kazimierza Twardowskiego dojrzewała u niego jeszcze w czasie pobytu i w Getyndze, i w Wiedniu. 6 września 1913 roku napisał z Wiednia do Twardowskiego:

$\mathrm{W}$ odpowiedzi na list $\mathrm{z}$ dnia 31. VIII. donoszę, że już dawniej miałem zamiar objęcia posady z dniem lgo października bez względu na to, czy obejmę ją jako asystent płatny czy wolontaryusz. Już we Wiedniu pozwoliłem sobie Szanownemu Panu Profesorowi powiedzieć, że asystenturę u Szanownego Pana Profesora mieć pragnę nie dla korzyści finansowych, lecz dla możności pracowania u boku Pana Profesora w obrębie koła, jakie swą działalnością Szanowny Pan Profesor we Lwowie zatoczył. Że jednak, skutkiem mego stanu finansowego, zdany jestem na zarobek, jest coprawda rzeczą ważną; w każdym razie w odniesieniu do motywów, którymi się $\mathrm{w}$ tej sprawie powoduję, strona finansowa ma znaczenie drugorzędne. Z końcem września zgłoszę się zatem u Pana Profesora.

\section{W ARmil austriackiej (1915) i w Wojsku Polskim W OBRONIE LWOWA (1919-1920)}

Dziewięć miesięcy później 26-letni Stefan Błachowski zostaje w wyniku mobilizacji wcielony do armii austriackiej. 23 czerwca 1915 roku, dzień po opuszczeniu Lwowa przez Rosjan, w mieście ukazuje się Obwieszczenie powołania mobilizacyjnego do armii C.K. i Kr[ólestwa] Węg[ier], w którym to obwieszczeniu czytamy:

Na podstawie Najwyższego zarządzenia zapowiedzenia całego c.k. i kr. węg. pospolitego ruszenia zostają wszyscy pospolitacy urodzeni w latach 1873 do 1897 włącznie, którzy nie pełnią jeszcze dotąd służby w armji wspólnej, marynarce wojennej, obronie krajowej, lub nie służą przy żandarmerii albo $\mathrm{w}$ pospolitym ruszeniu, pociągnięci do służby $\mathrm{z}$ bronią w pospolitym ruszeniu, o ile przy przeglądzie za zdatnych do tego uznani zostaną. Jawienie się do czynnej służby. Kiedy i gdzie uznani za zdatnych mają stanąć do czynnej służby, dowiedzą się o tem przy przeglądzie. Uznani za zdatnych przy dodatkowym przeglądzie mają narukować ${ }^{19}$

19 Narukować - z niemieckiego einrücken - „wstąpić”; tutaj: „zostać powołanym do wojska”. 
w przeciągu 48 godzin po ich przeglądzie. Zaniechanie albo spóźnienie narukowania karanem będzie w myśl wymienionej wyżej ustawy. (Kurier Galicyjski, 2015, s. 23)

Ze względu na stan zdrowia Błachowskiego jego ojciec zwraca się do rektora Kazimierza Twardowskiego z prośbą o wstawienie się za synem Stefanem u władz wojskowych. Mówi o tym list pisany do Twardowskiego w Wiedniu 16 października 1915 roku.

Jaśnie Wielmożny Panie Profesorze! Proszę zechcieć łaskawie wybaczyć, że ośmielam się mym listem trudzić, ale troska o los mego syna Stefana zmusza mię do tego kroku. Jaśnie Wielmożnemu Panu Profesorowi zapewne wiadomo, że Stefan już 5. miesiąc wojskowo służy, mimo że na serce niedomaga, gdyż obecnie na zaburzenia sercowe nie tyle się zważa, jak dawniej ${ }^{20}$. Pozwalam sobie o tem donieść, sądząc że tylko starania ze strony wszechnicy o Stefana jako asystenta na ulżenie jego losu wpłynąć mogą, o których łaskawe podjęcie najuprzejmiej proszę.

Interwencja Twardowskiego musiała być skuteczna, skoro trzy miesiące później, 12 stycznia 1916 roku Konstanty Błachowski pisze do niego z Wiednia z wyrazami serdecznego podziękowania: „Wasza Magnificencyo Jaśnie Wielmożny Panie Profesorze! Nie wiele piszę, ale usilnie proszę i odemnie przyjąć zechcieć słowa żywej wdzięczności za łaskawie wyświadczoną życzliwość i wyrazy wysokiego poważania, przyczem się kreślę uniżonym". Nie wiadomo jednak, który argument przeważył: niedopisujące zdrowie żołnierza czy jego praca na Uniwersytecie. Być może przywołane wcześniej tymczasowe zaświadczenie o immatrykulacji Stefana Błachowskiego na Wydział Filozoficzny Uniwersytetu Wiedeńskiego z datą 26 stycznia 1915 roku miało jakiś związek z jego zwolnieniem z wojska („zostałem na zasadzie reklamacji Uniwersytetu Lwowskiego zwolniony w styczniu 1916 r.”). Wszelako trzy lata później trzydziestoletni Stefan Błachowski ponownie znalazł się w armii: „W latach 1919-1920 służyłem w Wojsku Polskim jako kanonier w 14 pułku artylerii ciężkiej ${ }^{21}$. W dniu

20 W swoim Curriculum vitae, pisanym we Lwowie 14 stycznia 1919 roku, Stefan Błachowski wspominał: „od 21. czerwca 1915. do 1. stycznia 1916. służyłem wojskowo w 30. pułku piechoty, poczem znowu mogłem podjąć moje funkcye asystenckie we Lwowie" (Archiwum UAM, teczka o sygnaturze 15/611/3). O swoich kłopotach ze zdrowiem donosił już wcześniej Kazimierzowi Twardowskiemu w liście z 12 września 1912 roku. List był pisany w Bad Hall, miejscowości uzdrowiskowej w Austrii. „W tym tygodniu wyjeżdżam z Bad Hall, w którym mi się ze względu na mój stan zdrowia nie zbyt dobrze działo, na jeden miesiąc do Wiednia”. W ankiecie personalnej z datą 5 czerwca 1950 roku przechowywanej w Archiwum Polskiej Akademii Nauk w Warszawie Oddział w Poznaniu (sygn. P III-82) Stefan Błachowski napisał, że na przełomie roku 1918 i 1919 brał udział w kampanii lwowskiej jako ochotnik w artylerii konnej, a w 1920 roku znów jako ochotnik wchodził w skład I Poznańskiej Baterii ciężkich haubic francuskich, późniejszej 7 p. a. c.”. 
31. XII. 1929 zostałem przeniesiony do pospolitego ruszenia" - napisał później w swoim życiorysie.

Kiedy 19 października 1918 roku Ukraińska Rada Narodowa proklamuje państwo ukraińskie, stanie się to pretekstem do podjęcia próby opanowania Lwowa przez Ukraińców. W nocy z 31 października na 1 listopada dochodzi do tzw. ukraińskiego zamachu stanu. Z odsieczą do miasta przybyły oddziały wojsk polskich i dzięki tej akcji 22 listopada Lwów ponownie - po 146 latach znalazł się w rękach polskich. Mimo jednak udanej odsieczy miasto aż do 29 kwietnia 1919 roku pozostawało pod ostrzałem artylerii wroga (por. Kienzler, 2014). Kazimierz Twardowski zanotował: „27. grudnia, piątek [1918]: [...] Dzień był bardzo gorący; działa z miasta i peryferii biją jak jeszcze nigdy. Wszędzie wokoło miasta zacięte walki. Wodociąg przestał funkcjonować” (Jadczak, 1997, s. 76). I znów: „22. stycznia [1919], środa: O pierwszej uderza pocisk od strony ogrodu botanicznego w mur gmachu uniwersyteckiego, koło okien Czytelni Seminarium filozoficznego; [...] ja zaś byłem wtedy w Bibliotece Seminarium filozoficznego. Po południu w dalszym ciągu ostrzeliwanie miasta" (Jadczak, 1997, s. 82). Jedną z dzielnic Lwowa, w której toczyły się wówczas walki, był odległy od centrum miasta, położony za linią kolejową, Kulparków. Twardowski tak wspominał tamte wydarzenia: „29 stycznia, środa [1919]. Dziś miasta nie ostrzeliwano. Po południu odwiedzam Błachowskiego, który wczoraj po południu o wpół do czwartej jako artylerzysta cudem uszedł na pozycji na Kulparkowie śmierci. Granat uderzył tuż koło niego i zabił towarzysza broni $\{\ldots \mathrm{a}\}^{22}, \mathrm{z}$ którym rozmawiał. Błachowski doznał tylko kontuzji na czole, na plecach i na stopach" ${ }^{\text {23 }}$ (Jadczak, 1997, s. 83). Dwa dni później „31. stycznia, czwartek: [...] Odwiedzam przed południem Błachowskiego”, a już 12 lutego (środa): „Po południu odwiedza nas Błachowski, który jutro znowu - po 2-tygodniowym urlopie - wraca w szeregi" (Jadczak, 1997, s. 85).

\section{NASTAWIENIA I SPOSTRZEŻENIA (1917)}

Czas Wielkiej Wojny, który zbiegł się z pracą Stefana Błachowskiego na Uniwersytecie Lwowskim ${ }^{24}$ oraz z wyjazdami na studia uzupełniające do Wiednia

22 Nawias klamrowy z literą „a” wskazuje wyraz w części rękopiśmiennej dzienników Twardowskiego, którego Jadczakowi nie udało się odczytać (litera „b” mówi o braku dwóch wyrazów) (Jadczak, 1997, s. 13).

23 Jeszcze raz spojrzy śmierci w oczy w roku 1953, kiedy przejdzie ciężką operację, z której jak powie - „ledwie wyszedł z życiem”, i nie mniej ciężką chorobę pooperacyjną (morbus maculosa Werhofii), która na trzy miesiące zatrzymała go w łóżku.

24 W letnim półroczu 1917/1918, już jako docent prywatny, będzie miał tam dwie godziny wykładów z psychologii i jedną godzinę ćwiczeń. Ale wkrótce trudna sytuacja materialna zmusi go do przyjęcia od 1 lutego 1918 roku etatu asystenta w Bibliotece Uniwersyteckiej we Lwowie, na którym będzie zatrudniony do 8 lipca 1919 roku. Będzie to zarazem początek 
i Getyngi, nie tylko nie zakłócał jego rozwoju naukowego, lecz także wbrew wielu przeszkodom zewnętrznym i wewnętrznym inspirował do wzmożonego wysiłku (patrz: Stachowski, 2009), którego jednym z wymownych efektów jest rozprawa naukowa Nastawienia i spostrzė̇enia (Studyum psychologiczne), wydrukowana we Lwowie w 1917 roku nakładem Polskiego Towarzystwa Filozoficznego ${ }^{25}$. O owych przeszkodach u początków swojej pracy nad 93-stronicową rozprawą wspomina w Przedmowie:

W zimie 1914 r. w warunkach dla pracy naukowej nader niekorzystnych, zdala od rodzinnego kraju. Potem oderwała mnie od niej służba wojskowa na szereg miesięcy, a kiedy po przyjeździe do Lwowa znowu do niej wróciłem, musiałem pokonać liczne wewnętrzne i zewnętrzne przeszkody, by zadanie niegdyś sobie wytknięte doprowadzić do końca. Ślady tych niefortunnych wewnętrznych i zewnętrznych warunków widoczne są na wielu miejscach mej pracy. (Błachowski, 1917, s. 9)

Na stronie piątej Nastawień... wzrok przykuwa krótka dedykacja: „Pamięci brata mojego Romana, który poległ w bitwie pod Biórkowem małym [sic!] w dniu 18. listopada 1914". (Biórków Mały to wieś w woj. Małopolskim, która w dniach 17-20 listopada 1914 roku była terenem walki 2. c.k. strzelców tyrolskich oraz 59. c.k. pułku piechoty armii austro-węgierskiej z wojskami rosyjskimi).

Skoro zimą 1914 roku Błachowski - jak czytamy w Przedmowie - przebywał $\mathrm{z}$ dala od rodzinnego kraju, to mógł to być tylko Wiedeń, co potwierdzałoby wyrażone na wcześniejszej stronie przypuszczenie autora niniejszego artykułu, że owa problematyczna data 1914/1915 w indeksie odnosi się do planowanych w tymże roku akademickim studiów, do których jednak nie doszło.

Rozprawa Błachowskiego Nastawienia i spostrzeżenia stała się podstawą postępowania habilitacyjnego na Uniwersytecie Lwowskim, któremu przewodniczył Kazimierz Twardowski. Zakończyło się ono kolokwium habilitacyjnym w dniu 12 grudnia 1917 roku i nadaniem Stefanowi Błachowskiemu veniam docendi z psychologii (patrz: Stachowski, 2009, s. 28-29).

Początkowo Błachowski zamierzał opracować „całokształt psychologii spostrzeżeń”, które „w życiu psychicznem człowieka zajmują miejsce ważne i szerokie", ale w miarę pracy nad tym zagadnieniem coraz bardziej utwierdzał się w przekonaniu, że skoro „przedmiotami spostrzeżeń mogą być te wszystkie przedmioty, których ogół tworzy przyrodę, które dadzą się ugrupować bądźto w czasie i przestrzeni, jak przedmioty fizyczne, bądźto tylko w czasie, jak przebiegi psychiczne" (Błachowski, 1917, s. 45), zatem i nastawienia osoby spostrzegającej

jego związania się z Poznaniem i Uniwersytetem Poznańskim, gdzie 1 kwietnia 1919 roku (po udzieleniu mu przez Bibliotekę Uniwersytecką we Lwowie urlopu) otrzyma etat docenta. 
na te przeciwstawne klasy przedmiotów muszą się różnić. Przecież osobnik spostrzegający przedmioty fizyczne musi to robić z odpowiedniego oddalenia, przy odpowiednim oświetleniu itd., podczas gdy przedmiotami psychicznymi są osobiste doznania spostrzegającego. Spostrzeżenia będą się więc zmieniać $\mathrm{w}$ zależności od tego, w jakim nastawieniu znajduje się osoba spostrzegająca. Dlatego można nastawienia analizować w sposób pośredni, „niejako na kanwach spostrzeżeń”, co powinno ujawnić takie ich właściwości, „któreby się przy wgłębianiu w nastawienia jako takie były nie okazały" (Błachowski, 1917, s. 29).

Analizę psychologiczną wpływu nastawień na spostrzeżenia Błachowski ograniczył do dwóch rodzajów nastawień: ekstrospekcyjnych (naiwnych albo zewnętrznych) i introspekcyjnych (psychologicznych albo wewnętrznych). Wyraz ekstrospekcyjny, wprowadzony do psychologii przez Alfreda Bineta (1857-1911), „dobrze oddaje «kierunkowość» nastawienia, która jest jego najważniejszą cechą" (Błachowski, 1917, s. 32). Wyraz naiwny nie ma tutaj znaczenia ujemnego, lecz „oznacza bezpośrednie i pierwotne zwracanie się ku przedmiotom, jak to zarówno w życiu codziennem, jak i naukach przyrodniczych zwykliśmy czynić" (Błachowski, 1917, s. 32). Kiedy natomiast człowiek nastawia się albo jest nastawiony na przedmiot psychiczny, to znajduje się w nastawieniu psychologicznym, co znaczy, że ma do czynienia z przedmiotem psychicznym. Wyraz introspekcyjny również wskazuje na kierunkowość nastawienia, ale jednak przeciwną do kierunkowości nastawienia ekstrospekcyjnego.

Nasze życie codzienne jest zdominowane przez nastawienie naiwne; w nastawieniu psychologicznym trwamy bardzo krótko, szybko przyjmując ponownie nastawienie naiwne. Tę przewagę nastawienia naiwnego Błachowski tłumaczy genetycznie, tym, że:

przedmioty świata zewnętrznego już we wczesnem dzieciństwie narzucają się z wielką natarczywością psychice dziecięcej i zmuszają dziecko do zajęcia się nimi. W wieku, w którym w dziecku niewiele jeszcze dokonuje się przeżyć, już istnieje dla niego cały świat przedmiotów zewnętrznych, na które zwraca uwagę, którymi się żywo zajmuje, na które - jednem słowem - jest nastawione. (Błachowski, 1917, s. 41)

Z rozwojowego punktu widzenia owa dominacja nastawienia ekstrospekcyjnego nad nastawieniem introspekcyjnym jest zrozumiała, ponieważ „orientacya w świecie fizycznym dopiero czyni jednostkę zdolną do życia” (Błachowski, 1917, s. 88). Gdyby bowiem nastawienie introspekcyjne odgrywało w życiu człowieka taką rolę, jaką odgrywa w nim nastawienie naiwne, to taki człowiek:

byłby niezdatny do życia, nie umiałby się oryentować w świecie zewnętrznym, $\mathrm{z}$ trudem tylko potrafiłby uchwycić zajścia otaczającego go świata $\mathrm{i}$ - $\mathrm{z}$ powodu ciągłego popadania $\mathrm{w}$ nastawienie introspekcyjne nie dostrzegałby wątku zdarzeń. Świetny obserwator własnego życia 
psychicznego byłby niezdolnem do życia stworzeniem ${ }^{26}$. (Błachowski, 1917, s. 41)

Podstawę wszelkiej psychologii stanowi opis jej przedmiotu, którym są fakty psychiczne - mówi Błachowski. Chcąc te fakty zanalizować i opisać, psycholog musi je najpierw uobecnić ${ }^{27}$, a to można zrobić zależnie od tego, kto te fakty przeżywa, albo go nie uwzględniając. W pierwszym wypadku będzie to uobecnianie albo własnych przeżyć osoby (uobecnianie aktualne), albo przeżyć drugich (uobecnianie wczuwajace). I tak na przykład:

zajmuje się patopsychologia wyłącznie przeżyciami drugich, i to przeżyciami, które bądźto w analogiczny sposób się odbywają jak u badacza (wogóle u osób normalnych), bądźto są spotęgowaniem lub osłabieniem normalnych przeżyć, bądźto wreszcie posiadają zupełnie odrębny charakter, dzięki któremu w świadomości normalnego człowieka nigdy się nie znachodzą. (Błachowski, 1917, s. 11, przypis 2)

Do uobecniania wczuwającego dochodzi wtedy, „kiedy z min, ruchów, głosu i t. d. danej osoby (a zatem $z$ okazyi zewnętrznego spostrzeżenia) «odczytuje się» bezpośrednio przeżycia tej osoby, doznając przytem analogicznych przeżyć i uobecniając je sobie przy pomocy aktualnego uobecniania" (Błachowski, 1917, s. 12). W drugim natomiast wypadku fakty psychiczne uobecniać sobie można także wówczas, kiedy się tylko myśli o jakimś fakcie psychicznym albo o pewnej klasie faktów psychicznych bez względu na to, w czyim umyśle te fakty się dokonały. Ten sposób uobecniania nazywa Błachowski za Baadem uobecnianiem reprezentującym (Błachowski, 1917, s. 12-13).

Jednak sam opis zdarzeń psychicznych, niezależnie od sposobu ich uobecniania, nie wyczerpuje zdaniem Błachowskiego zadania psychologii, jakim jest wykrycie zachodzącego między nimi związku oraz poznanie przyczyn, dzięki którym przeżycia zjawiają się w świadomości i w niej zachodzą. Do opisu służą pojęcia opisowe, poszukiwany związek natomiast oraz przyczyny są określane

26 W każdym z tych nastawień Błachowski wyróżnia jego stronę dyspozycyjną i aktualizacyjną (czyżby nawiązanie do Arystotelesowskiej możności i aktu w bycie?) (Błachowski, 1917, s. 40). Przewagę dyspozycji do nastawienia naiwnego nad dyspozycją do nastawienia psychologicznego tłumaczy z jednej strony większą jej siłą i trwałością, z drugiej - genetycznie, bowiem dziecko ma więcej sposobności do aktualizacji dyspozycji do nastawienia ekstrospekcyjnego niż dyspozycji do nastawienia introspekcyjnego. Zdaniem Błachowskiego zaczątki życia psychicznego u dziecka nie zbiegają się czasowo z powstaniem dyspozycji do nastawienia introspekcyjnego, ponieważ ta ostatnia nie jest jakąś ogólną dyspozycją do powstawania faktów psychicznych ogólnie rzecz biorąc, lecz tylko dyspozycją do ujmowania ich przez wewnętrzne skierowanie się w ich stronę (por. Błachowski, 1917, s. 87).

27 Swoje wywody o uobecnianiu (Vergegenwärtigung) Błachowski oparł na jednej z prac Waltera Baadego (1881-1922), psychologa z Getyngi. 
przez pojęcia funkcyjne (ten podział pojęć Błachowski zapożyczył od Kurta Koffki [1886-1941]).

W tym miejscu Błachowski porusza jeden z najbardziej zawiłych i dokuczliwych problemów ówczesnej psychologii: kwestię istnienia funkcji jako elementów świadomości. Podział elementów świadomości na dwie klasy: klasę zjawisk (np. wrażenia i wyobrażenia) oraz klasę funkcji (np. akty poznawania, uczuć i woli ${ }^{28}$ doprowadził do wyodrębnienia się psychologii sensualistycznej (asocjacyjnej), której jednym z głównych przedstawicieli był Georg Elias Müller, oraz tzw. psychologii funkcyjnej, którą reprezentowali m.in. Edmund Husserl (1859-1938), Theodor Lipps (1851-1914), Oswald Külpe (1862-1915) i Karl Ludwig Bühler (1879-1963). W przeciwieństwie do psychologii funkcyjnej psychologia asocjacyjna sprowadzała wszystkie przeżycia do zjawisk (wyobrażeń) i do ich kojarzenia, usuwając zarazem funkcje $z$ dziedziny psychologii.

Jak z tego wynika, pojęcie czynności psychicznych, czyli funkcji, jest w obrębie psychologii sensualistycznej pojęciem funkcyjnym, w obrębie psychologii funkcyjnej natomiast - pojęciem opisowym. Funkcje jako pojęcia opisowe wykazują w porównaniu ze zjawiskami pewną „nieprzystępność dla introspekcyi [...] Istotę tej różnicy między zjawiskami a funkcyami określić możemy także na zasadzie naszych wstępnych wywodów, stwierdzając, że zjawiska dane nam być mogą $\mathrm{w}$ aktualnem uobecnieniu, kiedy natomiast funkcyi nie można sobie aktualnie uobecnić" (Błachowski, 1917, s. 17).

Z przyjętego przez Błachowskiego podziału nastawień na nastawienia ekstrospekcyjne i introspekcyjne wynika ważna różnica między przedmiotami spostrzegania lub ich własnościami. Pojęcie przedmiotu obejmuje tutaj swoim zakresem „wszystko, co kiedykolwiek było lub może być "przedmiotem dla nas»" (Błachowski, 1917, s. 43). W tak szerokim znaczeniu, typowym dla psychologii współczesnej Błachowskiemu, występuje ono u Kazimierza Twardowskiego: „Wszystko, co można sobie przedstawić przez przedstawienie, uznać lub odrzucić przez sąd, pożądać lub odepchnąć przez akt emocji - nazywamy «przedmiotem». Przedmioty są realne albo nierealne, możliwe albo niemożliwe, istnieją lub nie istnieją" (Twardowski, 1965, s. 33). Innymi słowy, „do istoty spostrzegania należy spostrzeganie czegoś, jakiegoś przedmiotu" - konkluduje Błachowski (1917, s. 43). Ukazana wcześniej różnica między przedmiotami spostrzegania psychicznymi i fizycznymi polega na tym, że introspekcyjnie spostrzegany przedmiot psychiczny, czyli przeżycie, istnieje tylko dla osoby spostrzegającej go w introspekcji, przedmiot fizyczny natomiast, nie będąc przeżyciem, istnieje także dla innych, czyli może się stać przedmiotem spostrzegania także dla drugich. Mając na względzie tę różnicę, Błachowski uważa, że termin Erlebniswahrnehmung, zaproponowany przez Koffkę, zasługuje na rozpowszechnienie, ponieważ „lepiej niż

28 U Kazimierza Twardowskiego odpowiednikiem funkcji jest czynność psychiczna przeciwstawiona wytworowi psychicznemu, na przykład: myśleć-myśl, pojmować-pojęcie itd. 
terminy Selbstbeobachtung albo Selbstwahrnehmung wyraża, jakie przedmioty mamy na myśli, o co nam chodzi, gdy zwracamy się ku spostrzeganiu naszych własnych stanów wewnętrznych" (Błachowski, 1917, s. 45-46).

Wszystko to prowadzi niechybnie do wniosku, że tradycyjne odróżnienie aktu od treści i od przedmiotu w dziedzinie spostrzeżeń musi się odnosić tylko do spostrzegania przedmiotów fizycznych.

Tylko bowiem w tym przypadku mogę mówić o przedmiocie, który istnieje poza mną, o treści, w której mi się przedmiot ów przedstawia, i o akcie, dzięki któremu przedmiot ów za pośrednictwem treści staje się przedmiotem mego spostrzeżenia. Kiedy natomiast chodzi o spostrzeżenie własnych stanów psychicznych, zauważyć nietrudno, że przedmiot jest zarazem treścią spostrzeżenia. Stan introspekcyjnie spostrzeżony przedstawia nam się w postaci najpierwotniejszej i takim, jakim jest w istocie swej; treść, w której się on nam zjawia, wyczerpuje zupełnie przedmiot, a nawet więcej: treść owa nie jest niczem innem niż przedmiotem samym. (Błachowski, 1917, s. 46)

Można przeto zasadnie zapytać, jak jednorazowe i niepowtarzalne dane nastawienia introspekcyjnego mogą być przedmiotem badań naukowych? Nie można ich przecież nie tylko obserwować, ale nawet tego samego zjawiska nie sposób po raz drugi wywołać w celu oglądania go. Z tych właśnie względów mówi Błachowski - „psychologia różni się zasadniczo od nauk przyrodniczych; a różnica ta polega $\mathrm{w}$ istocie swej na tem, że nauki przyrodnicze badają dane nastawienia naiwnego, psychologia zaś zajmuje się danemi nastawienia introspekcyjnego" (Błachowski, 1917, s. 58).

I tak oto Stefan Błachowski dociera do sedna pytania o możliwość z jednej strony psychologii jako nauki, $\mathrm{z}$ drugiej - wynalezienia i stosowania odpowiednich metod:

Do dziś dnia toczy się nad temi sprawami dyskusya, która nie tak rychło zapewne zamilknie. Ściśle rzecz biorąc istnieją tylko różnorodne, nigdy się nie powtarzające zjawiska psychiczne, ulegające tylko jednorazowemu ujęciu w spostrzeżeniu. W badaniach psychologicznych postępujemy jednak tak, jakgdyby zjawiska psychiczne zjawiały się nam w dowolnej ilości (ewentualnie sztucznie wywołane) jako te same. Dla praktycznego przeprowadzenia psychologii zamykamy oczy na pewne postulaty teoretyczne, abstrahujemy od tego, że do istoty nastawienia introspekcyjnego należy, iż dane w niem zjawiska nigdy nie są ze sobą identyczne - i zjawiska, różniące się między sobą lecz posiadające takie właściwości, że ich dla tych właściwości możemy ściągnąć w pewne grupy, traktujemy tak, jakgdyby były temi samemi zjawiskami. (Błachowski, 1917, s. 59)

Mimo to istnienie dwóch zasadniczo różniących się nastawień - konkluduje jest niepodważalnym faktem (Błachowski, 1917, s. 60). Z tych nastawień jedno 
obejmuje sferę przedmiotów zewnętrznych, drugie zaś - sferę treści psychicznych. Są to sfery „toto genere od siebie różne i w różny sposób przez opisującego je uchwytne" (Błachowski, 1917, s. 60). Pozostaje jeszcze do rozstrzygnięcia kwestia ulotnego charakteru aktualizacji, czyli strony zjawiskowej czynnej dyspozycji do nastawień, zwłaszcza dyspozycji do nastawienia naiwnego. Ale „na kwestie te da może kiedyś zadowalającą odpowiedź powstająca w dzisiejszych czasach psychologia rozwoju" - kończy swoją rozprawę Błachowski (1917, s. 89).

Nie od rzeczy byłoby chyba teraz zapytać o to, czy i jaki oddźwięk w świecie nauki wywołała rozprawa Stefana Błachowskiego z roku 1917. Mimo że jej autor powołuje się na prace ówczesnych czołowych przedstawicieli psychologii europejskiej, głównie niemieckiej, nie mógł przecież liczyć na rozgłos światowy, skoro książka była napisana w jego języku ojczystym. A jak było w Polsce? Za życia Błachowskiego Nastawienia i spostrzeżenia zostały zauważone przez dwóch psychologów. Już w roku 1919 na łamach redagowanego przez Kazimierza Twardowskiego „Ruchu Filozoficznego” (V, 1, 7-8) ukazała się krótka recenzja sprawozdawcza rozprawy habilitacyjnej Błachowskiego pióra Mieczysława Kreutza (1893-1971), psychologa na Uniwersytecie Lwowskim. Jednak jej autor poprzestał wyłącznie na ogólnym opisie treści książki.

Ponad 30 lat później praca Błachowskiego doczekała się uznania - co ciekawe u przedstawiciela psychologii materialistycznej, Tadeusza Tomaszewskiego ${ }^{29}$, 41-letniego profesora nadzwyczajnego psychologii i kierownika Katedry Psychologii Ogólnej na Uniwersytecie Warszawskim, przejętej w roku 1949 po Władysławie Witwickim (1878-1948). W dniach 10-11 kwietnia 1951 roku odbywała się w Warszawie II Ogólnopolska Konferencja Pedagogów i Psychologów. $\mathrm{W}$ pierwszym dniu jej obrad Tomaszewski wygłosił referat pt. Kryzys metodologiczny w psychologii. Po dodaniu przypisów rozwijających niektóre myśli oraz odpowiedzi na głosy $\mathrm{w}$ dyskusji referat ukazał się rok później drukiem w pierwszym numerze inaugurującego swoją powojenną działalność „Przeglądu Psychologicznego". Nie mogło być odpowiedniejszego miejsca dla tego artykułu niż łamy nowego czasopisma psychologicznego, które:

[...] podejmując wskazania I Kongresu Nauki Polskiej, pragnie w jak najszerszym zakresie przyczynić się do włączenia pracy naukowej polskich psychologów do wielkich zadań związanych z budownictwem socjalizmu w naszym kraju, z realizacją planu 6-letniego i z procesem przekształcania się naszego narodu w naród socjalistyczny. (Od Redakcji, 1952, s. III-IV ${ }^{30}$ )

29 Jeszcze w roku 1963 Tomaszewski (1910-2000) przypominał, że na jego własny sposób myślenia najsilniej wpłynęły materializm dialektyczny i pawłowizm (Tomaszewski, 1963, s. 6).

30 Wprawdzie w przywołanym numerze „Przeglądu Psychologicznego” z jakichś tajemniczych powodów nie zamieszczono stopki redakcyjnej, jednak nie jest żadną tajemnicą, że jego redaktorem naczelnym był Stefan Błachowski. Jest bardzo prawdopodobne, że treść przedsłowia (Od Redakcji) była upozorowanym wyrazem jego wejścia w kompromis między nim a urzędową cenzurą, a może nawet autocenzurą zespołu redakcyjnego. 
Bezpośredniej przyczyny kryzysu metodologicznego w psychologii powojennej Tomaszewski upatrywał w bankructwie metody testów i metody introspekcji. Tradycyjna koncepcja introspekcji, uchodząca w psychologii burżuazyjnej za metodę podstawową, jest jego zdaniem „zgodna z ogólnym duchem psychologii burżuazyjnej, [...] istotnie abstrahuje [...] zupełnie od przedmiotów obiektywnych i [...] to właśnie jest jej słaba strona, która czyni ją bezradną wobec nowej problematyki psychologicznej" (Tomaszewski, 1952, s. 28, przypis 11; por. Zeidler, 2008, s. 132-133). Jednak - jak przyznaje Tomaszewski:

W praktyce psychologowie bardzo często odstępowali od konsekwentnych pozycji introspekcyjnych, tak samo jak behawioryści w konkretnych badaniach nie zawsze umieli utrzymać się na stanowisku konsekwentnie behawiorystycznym. Tej niekonsekwencji zawdzięczamy, że i jedni i drudzy zdołali mimo swoich zasad ogólnych odkryć niemało cennych prawidłowości o wartości obiektywnej. Ale obecne nasze zadania tak silnie związane są z koniecznością poznawania rzeczywistości obiektywnej, że nie możemy już polegać tylko na niekonsekwencjach badaczy, lecz musimy odrzucić wyraźnie takie zasady ogólne, przy których wartościowe wyniki są możliwe jedynie wtedy, gdy badacz sprzeniewierzy się swoim własnym zasadom. (Tomaszewski, 1952, s. 30-31, przypis 12)

\section{I kontynuuje:}

Konfrontując przedstawiony tu pogląd z naszą literaturą psychologiczną, znalazłem jedno zdanie teoretyczne, do którego można by pogląd ten nawiązać. Zdanie to [jest] zawarte w pracy prof. S. Błachowskiego pt. Nastawienia i spostrzeżenia na str. 64. Brzmi ono następująco: „Analiza spostrzeżenia przedmiotów psychicznych musi uwzględnić także stosunek tychże do przedmiotów fizycznych, a tem samem poniekąd także same przedmioty fizyczne”. Użyte tu wyrażenie „spostrzeżenie przedmiotów psychicznych" znaczy tyle co poznawanie własnych zjawisk psychicznych. Autor twierdzi zatem wyraźnie, że poznawanie zjawisk psychicznych wymaga znajomości tych przedmiotów fizycznych, do których te zjawiska psychiczne się odnoszą.

Jest to dość wyjątkowe zdanie nie tylko w polskiej literaturze, ale o ile mi wiadomo - także i w literaturze światowej. Tkwi ono samotnie w świadomie (choć nie całkiem konsekwentnie) materialistycznej [wyróżnienie R.S.] rozprawie prof. Błachowskiego z roku 1917 niezauważone przez psychologów i niepodejmowane więcej nawet przez samego autora. Małe ziarno polskiej psychologicznej tradycji postępowej, któremu czas najwyższy pozwolić się rozwinąć. [...] Przedmiotowość jest tak samo istotną cechą działania jak i procesów psychicznych. (Tomaszewski, 1952, s. 31-32) 
Wprawdzie trudno mi się zgodzić z uznaniem przez Tomaszewskiego rozprawy Błachowskiego z 1917 roku za „świadomie (choć nie całkiem konsekwentnie) materialistyczną" (por. Stachowski, 2011), nie sposób jednak nie przyznać mu racji wtedy, gdy mówi, że temu małemu ziarnu polskiej psychologicznej tradycji postępowej czas najwyższy pozwolić się rozwinąć. Jakkolwiek nie było mu dane rozwinąć się na gruncie polskiej myśli psychologicznej, to przynajmniej - wbrew pesymizmowi Tomaszewskiego - nie zostało przecież przez psychologów zignorowane.

Niemal pół wieku później, już po śmierci autora Nastawień $i$ spostrzeżeń, Bolesław Hornowski (1914-1983), od 1948 roku współpracownik Stefana Błachowskiego w Katedrze Psychologii Uniwersytetu Poznańskiego, napisze: „Rozważania zawarte w tej rozprawie mają swój sens i znaczenie obecnie, szczególnie gdy o nastawieniach mówimy w sensie "postaw», co znane jest np. $\mathrm{w}$ angielskiej terminologii psychologicznej jako attitude lub set" (Hornowski, 1963, s. 16). Do książki Błachowskiego nawiąże ponownie pod koniec ubiegłego wieku, nie rozwijając swojej myśli, Zygmunt Zimny (1923-2012), dawny uczeń Stefana Błachowskiego w Poznaniu. W jednej ze swoich prac poświęconych psychologiczno-filozoficznym podstawom współczesnej matematyki, w rozdziale omawiającym klasyczną i atrybutywistyczną aksjomatykę teorii zbiorów Zimny (1996, s. 108) napisze: „sytuacja zadaniowa jest spostrzegana na skutek nastawienia i odpowiednich spostrzeżeń szczegółowych wynikających z postawionego celu (Błachowski S., 1917)".

Można tylko żałować, że nie licząc tych znanych mi jednostkowych odniesień do rozprawy Błachowskiego z 1917 roku, nie odcisnęła się ona na rodzimej myśli psychologicznej. A była przecież z jednej strony wyrazem sprawności naukowej autora (nie zapominajmy, że zaczął on ją pisać z dala od rodzinnego kraju zimą 1914 roku w okolicznościach nader niesprzyjających pracy naukowej, do tego jeszcze pracy przerwanej służbą wojskową), z drugiej stanowiła trwałe dobro nauki (rozprawą tą Błachowski włączał się w przewodni nurt badań ówczesnej psychologii europejskiej, głównie niemieckiej).

\section{KU IDEALOWI DALEKIEJ PRZYSZLOŚCI PSYCHOLOGII}

U schyłku życia Stefan Błachowski zastanawiał się jeszcze, czy zrobił dobrze, obierając drogę naukową. Na wybór drogi życiowej prowadzącej przez doświadczenia Wielkiej Wojny nie miał żadnego wpływu. Jednak na każdej z tych dróg pozostał wierny wybranej przez siebie psychologii. Niemal w przededniu I wojny światowej napisał:

Dwa są jednak cele, których osiągnięcie - poza czysto naukową tendencyą poznania - stanowi ideał dalekiej przyszłości psychologii: poznanie siebie samego i poznanie drugich. [...] Ze zrozumienia siebie samego wyniknie 
wyrozumiałość dla drugich. A w niej tkwi początek sprawiedliwszej oceny uczynków i łatwiejszego współżycia w rodzinie i społeczeństwie. Wielka ilość nieporozumień i zwad powstaje na tle nieuwzględnienia właściwości duchowych bliźnich, a nieuwzględnienie tychże właściwości częstokroć nie jest objawem złej woli, lecz tylko braku zrozumienia i wyrozumiałości. (1912, s. 266-267)

Powyższy tekst, powstały na „wygnaniu getyngeńskim”, ujrzał światło dzienne w kraju rodzinnym jego autora w miesięczniku kulturalnym dla młodzieży „Filareta” dwa lata przed Wielką Wojną. Wojną, w której nie było ani wyrozumiałości dla drugich, ani sprawiedliwszej oceny ich uczynków, za to niemało nieporozumień i zwad. Tymczasem Błachowskiemu nadarzyła się sprzyjająca okazja do wykazania się we własnym życiu owym „zrozumieniem i wyrozumiałością dla drugich", a dostarczył jej sam promotor jego rozprawy doktorskiej w Getyndze. Z drugiej strony wspominany już tutaj Tadeusz Zaworski ze swoich czasów studenckich w latach 1927-1931 zapamiętał, że „Profesor dużo opowiadał [...] o swej przygodzie doktorskiej w Getyndze" (Zaworski, 1994, s. 5). Co więc takiego wydarzyło się w tej fazie życia Błachowskiego „naprawdę nieprzyjemnej” - jak to sam określił w liście do Twardowskiego z Getyngi 12 września 1912 roku? Wróćmy zatem raz jeszcze do tamtych chwil.

Przedmiotem badań rozpoczętych przez Błachowskiego w roku 1909, po przyjeździe na Uniwersytet w Getyndze, stały się zjawiska kontrastu, a w szczególności rola pól kontrastujących, które miały stanowić treść planowanej przez niego rozprawy doktorskiej. Ukończoną rozprawę wręczył swojemu promotorowi, profesorowi Müllerowi, 15 lipca 1912 roku, licząc na to, że będzie mógł zdać doktorat jeszcze w roku akademickim 1911/1912 (dobiegającym już końca). Jednak ku jego wielkiemu zaskoczeniu i wewnętrznemu sprzeciwowi, nazajutrz po złożeniu przez Błachowskiego egzemplarza rozprawy Müller zwrócił mu go. Argumentację promotora Błachowski przytacza następująco: „że w tem półroczu nie może jej już z powodu braku czasu przeczytać, że więc czekać muszę do półrocza następnego" 31 . Z nutą goryczy pisze więc dalej do swojego Mistrza we Lwowie:

Że mię cała ta sprawa niezmiernie przygnębiła, jest zapewne rzeczą naturalną. Ale pewna gorycz przymieszała się do tego na myśl, że Prof. M. z tego powodu pracy nie chciał teraz czytać, że pisałem jej [sic!] nie radząc się jego, nie prosząc o jego pomoc. Wiedziałem wprawdzie, że Prof. M. chętnie widzi, jeśli uczniowie jego w każdej drobnostce się do niego odnoszą; jest tu parę pań, które o psychologii mniej wiedzą niż u nas dobry uczeń VIII kl. gimn., a mimo to mieć będą dobre wydrukowane prace. Ale właśnie tego rodzaju praca zmusza mię do opozycji, choćby tylko wobec siebie samego. Skutek jest jednak ten, że tracę na tym pół roku czasu. Nie

31 List Błachowskiego do Twardowskiego pisany w Getyndze, datowany na 30 lipca 1912 roku. 
wiem, jak Szanowny Pan Profesor na kwestię tę się zapatruje. Ale proszę łaskawie zważyć, że gdybym się był wdawał - wie hier üblich - w pertraktacje z Prof. M. byłbym stracił prawo nazwania mej pracy samodzielną, choćby wobec siebie samego. A przecież tylko na tym mi zależy.

Pół roku po zawodzie, jaki go spotkał ze strony promotora, 23 stycznia 1913 roku Błachowski zwraca się z wnioskiem do władz uczelni o dopuszczenie do egzaminu doktorskiego. Do wniosku dołącza pracę doktorską wraz z prośbą o uznanie egzaminu z psychologii za główny przedmiot przewodu doktorskiego, egzaminów z fizyki oraz z filozofii natomiast - za rygory (i przedmioty) uzupełniające (por. Głombik, 1999, s. 94). Okazało się, że Müller znalazł jednak pod koniec lutego czas nie tylko na przeczytanie rozprawy (czyżby za wstawiennictwem Kazimierza Twardowskiego?), lecz także na jej zrecenzowanie z ogólną oceną zadowalającą (idoneum) (por. Głombik, 1999, s. 94). Praca doktorska została ogłoszona drukiem jeszcze w tym samym roku ${ }^{32}$. Egzamin ustny z psychologii (Georg Müller) oraz z fizyki (Eduard Riecke) i filozofii (Heinrich Maier) odbył się 5 marca 1913 roku i zakończył oceną cum laude (por. Głombik, 1997, s. 150). Tym samym dobiegł końca bez mała czteroletni (od „Michała” 1909 do wiosny 1913) pobyt Stefana Błachowskiego w Getyndze. Opuszczał ją - mimo że „cała ta sprawa niezmiernie go przygnębiła” - już jako dwudziestoczteroletni doktor filozofii w zakresie psychologii, filozofii i fizyki.

Przedtem jednak zdobędzie się jeszcze na bezinteresowny gest zrozumienia i wyrozumiałości dla drugich ${ }^{33}$. Nie zważając na to, jak bardzo mu zależało na tym, żeby nie „stracić prawa do nazwania swojej rozprawy doktorskiej sa-

32 Studien über den Binnenkontrast. J.A. Barth in Leipzig: Göttingen 1913, s. 43. Także odbitka w: Błachowski, S. (1913). Studien über den Binnenkontrast. Zeitschrift für Sinnesphysiologie (rozdz. II. Abteilung der Zeitschrift für Psychologie und Physiologie der Sinnesorgane), 47(4/5), 291-330. Rozprawa Błachowskiego z roku 1913 nie tylko nie poszła w zapomnienie, lecz także powołują się na nią dzisiaj niektórzy badacze (patrz na przykład: Westheimer, G. (1967). Spatial interaction in human cone vision, Journal of Physiology, 190, 139-154); Malania, M., Herzog, M.H. i Westheimer, G. (2008). Grouping of contextual elements that affect vernier thresholds, Journal of Vision, 7(2), 1-7.

33 Warto przy okazji wspomnieć o jeszcze jednym, aczkolwiek późniejszym przykładzie takiej postawy Stefana Błachowskiego. W roku 1955, kiedy to w kręgach partyjnych narodziła się myśl o wyborze patrona Uniwersytetu Poznańskiego, na Radzie Wydziału Filozoficzno-Historycznego w dniu 10 listopada prof. Janusz Pajewski (1907-2003) zaproponował Adama Mickiewicza. „Prof. Stefan Błachowski, «wielka w uczelni powaga», tak ustosunkował się do propozycji prof. Pajewskiego: "Myśl ta jest bardzo mądra i niezwykle sympatyczna»" (Trzeciakowski, 1994, s. 481). Wprawdzie na posiedzeniu Senatu 12 dni później kandydatura ta nie spotkała się z powszechnym poparciem, ale po burzliwej, ostrej, obfitującej w liczne starcia dyskusji ostatecznie przeszła znakomitą większością głosów i w dniu 31 grudnia 1955 roku została zatwierdzona przez Radę Ministrów. „Uzyskanie takiego patrona” - przypomina Lech Trzeciakowski (1994, s. 481) - „było w owych czasach wyjściem, które uznać należy za najszczęśliwsze $\mathrm{z}$ możliwych. Oddawały to słowa prof. Błachowskiego, który w rozmowie z obecną na uroczystościach [11 lutego 1956 roku odbyła się z tej okazji uroczysta 
modzielną, choćby wobec siebie samego”, napisze w jej zakończeniu: „Jest mi niezmiernie miło wyrazić mojemu wielce szanownemu Nauczycielowi Panu Prof. G.E. Müllerowi serdeczne podziękowanie za wielostronne inspiracje i daleko idącą życzliwość, bez których ta praca zapewne nigdy by nie powstała" (Błachowski, 1913, s. 330; tłumaczenie i wyróżnienie R.S.). Można by ten komplement poczytać za zwyczajowy gest kurtuazji ze strony młodego doktora, który mógł nareszcie wrócić $\mathrm{z}$ „wygnania getyngeńskiego”, gdyby nie jego wewnętrzne przekonanie wyrażone w poniższym fragmencie:

Dusza człowieka jest oceanem bajecznych głębi i [...] to, co z niej uchwycić zdołamy, jest jakby fale, które tylko migotają na powierzchni. W głębi zaś tego oceanu dokonują się przemiany, o których wieść dochodzi do świadomości w postaci mglistych przeczuć, bezprzedmiotowych tęsknic i marzycielskich snów. Jest w każdej duszy człowieczej coś, co jest źródłem jej uroku: jej odrębna indywidualność. A tej we formułki ogólne badacza, mozołem pracy stworzone, ująć nie sposób. (Błachowski, 1912, s. 268)

\section{Bibliografia}

Białynia Chołodecki, J. (1930). Lwów w czasie okupacji rosyjskiej (3 września 1914-22 czerwca 1915). Z własnych przeżyć i wspomnień. Lwów: Drukarnia L. Wiśniewskiego.

Błachowski, S. (1912). Czem jest i czem będzie psychologia? Filareta, II(9), 263-268.

Błachowski, S. (1913). Studien über den Binnenkontrast. Zeitschrift für Psychologie und Physiologie der Sinnesorgane (rozdział II. Zeitschrift für Sinnesphysiologie), 47(4/5), 291-330.

Błachowski, S. (1917). Nastawienia i spostrzeżenia. (Stydyum psychologiczne) (tom IX). Lwów: Nakładem Polskiego Towarzystwa Filozoficznego. Z drukarni Jakubowskiego i Sp.

Błachowski, S. (1938). Kazimierz Twardowski. Kwartalnik Psychologiczny, 10, 1-8. Błachowski, S. (1947). Po ośmiu latach. Kwartalnik Psychologiczny, 13, vi-xvi.

Gajak-Toczek, M. (2010). Męskie gimnazja państwowe we Lwowie w latach 1772-1914. Acta Universitatis Lodziensis, Folia Litteraria Polonica, 13, 349-358.

Gajak-Toczek, M. (2011). Dzieje V Gimnazjum Państwowego we Lwowie - wydarzenia, fakty, sylwetki uczniów i nauczycieli. Acta Universitatis Lodziensis, Folia Litteraria Polonica, 14(2), 212-224.

akademia - przyp. R.S.] wszechwładną wtedy panią wiceminister Eugenią Krassowską, na jej pytanie, jak odpowiada mu nowy patron, odpowiedział ponoć krótko: «Aktualny w każdym reżimie»". 
Głombik, C. (1999). Stefan Błachowski i lata jego studiów getyngeńskich. W:

C. Głombik, Husserl i Polacy. Pierwsze spotkania, wczesne reakcje (s. 71-106).

Katowice: Wydawnictwo Gnome.

Hornowski, B. (1963). Życie i działalność Prof. dra Stefana Błachowskiego.

Przeglad Psychologiczny, t. 6, 7-29.

Jadczak, R. (1990). Wojenny rektorat Kazimierza Twardowskiego. Studia

Historyczne, 33(3-4), 423-442.

Jadczak, R. (red.). (1997). Kazimierz Twardowski. Dzienniki. Część I (1915-1927).

Toruń: Wydawnictwo Adam Marszałek.

Kienzler, I. (2014). Zwycięskie bitwy Polaków. 1919 Lwów. Warszawa: Wydawnictwo

Bellona.

Kreutz, M. (1919). (Recenzja) Błachowski Stefan. Nastawienia i spostrzeżenia (Studyum psychologiczne). Lwów. Nakładem Polskiego Towarzystwa Filozoficznego. Ruch Filozoficzny, V(1), 7-8.

Lewandowski, I. (2004). Jan Sajdak. W: T. Schramm (red.). Poczet rektorów

Almae Matris Posnaniensis (s. 81-92). Poznań: Wydawnictwo Naukowe Uniwersytetu im. Adama Mickiewicza w Poznaniu.

Lück, H.E. (2008). Historia psychologii. Orientacje, szkoły, kierunki rozwoju.

Warszawa: Vizja Press\&IT.

Matysiak, J. (2004). Stefan Błachowski. W: T. Schramm (red.), Poczet rektorów Almae Matris Posnaniensis (s. 156-166). Poznań: Wydawnictwo Naukowe Uniwersytetu im. Adama Mickiewicza w Poznaniu.

Od Redakcji (1952). Przegląd Psychologiczny, 1, III-VI.

Reutt, J. (1962). Stefan Błachowski (1889-1962). Ruch Filozoficzny, XXI(3), 245-249.

Rzepa, T. (1991). Psychologia Władysława Witwickiego. Poznań: Wydawnictwo Naukowe Uniwersytetu im. Adama Mickiewicza w Poznaniu.

Rzepa, T. (1992). Twardowski Kazimierz Jerzy Adolf ze Skrzypny Ogończyk.

W: E. Kosnarewicz, T. Rzepa, R. Stachowski (red.), Słownik Psychologów Polskich (s. 198-202). Poznań: Zakład Historii Myśli Psychologicznej UAM. Rzepa, T. (1993). O postawie nieinterwencji. Ruch Filozoficzny, L(3), 316-323.

Rzepa, T., Dobroczyński, B. (2009). Historia polskiej myśli psychologicznej. Gałazki z drzewa psyche. Warszawa: Wydawnictwo Naukowe PWN.

Sprawozdanie dyrekcyi C. K. Gimnazyum V. we Lwowie za rok szkolny 1900 (1900). Lwów: Nakładem Funduszu Naukowego.

Sprawozdanie dyrekcyi C. K. Gimnazyum V. we Lwowie za rok szkolny 1902 (1902). Lwów: Nakładem Funduszu Naukowego.

Sprawozdanie dyrekcyi C. K. Gimnazyum V. we Lwowie za rok szkolny 1905 (1905). Lwów: Nakładem Funduszu Naukowego.

Sprawozdanie dyrekcyi C. K. Gimnazyum V. we Lwowie za rok szkolny 1907 (1907). Lwów: Nakładem Funduszu Naukowego. 
Stachowski, R. (2009). Wstęp. Stefan Błachowski. Założyciel poznańskiej psychologii. W: R. Stachowski (red.), Stefan Błachowski. Założyciel poznańskiej psychologii (seria: Klasycy nauki poznańskiej, tom 31; s. 9-42). Poznań: Poznańskie Towarzystwo Przyjaciół Nauk i Uniwersytet im. Adama Mickiewicza.

Stachowski, R. (2011). Spór o introspekcję. Tadeusz Tomaszewski kontra Mieczysław Kreutz. W: T. Rzepa, C.W. Domański (red.), Na drogach i bezdrożach historii psychologii, t. 1, (s. 229-248). Lublin: Wydawnictwo UMCS. Szymański, K. (2015). Koniec okupacji 1915. Kurier Galicyjski, 12(232), 22-23.

Tomaszewski, T. (1952). Kryzys metodologiczny w psychologii. Przeglad Psychologiczny, 1, 1-35.

Tomaszewski, T. (1963). Wstęp do psychologii. Warszawa: Państwowe Wydawnictwo Naukowe.

Trzeciakowski, L. (1994). Dzieje Wydziału Filozoficznego. W: Kronika Miasta Poznania, 3-4 (s. 475-490). Poznań: Wydawnictwo Miejskie.

Twardowski, K. (1965/1894). O treści i przedmiocie przedstawień. W: K. Twardowski, Wybrane pisma filozoficzne (s. 3-91). Warszawa: Państwowe Wydawnictwo Naukowe.

Zaworski, T. (1994). Stefan Błachowski - profesor nie oficjalnie. Szkice do wizerunku. Biuletyn Oddziału Poznańskiego Polskiego Towarzystwa Psychologicznego, 3, 3-8.

Zeidler, W. (2008). Najważniejsze spory o przedmiot i metodę. W: R. Stachowski, W. Zeidler (red.), Opisowa metodologia badań psychologicznych. Studia i przykłady (s. 117-161). Warszawa: Vizja Press\&IT.

Zimny, Z.M. (1996). System a zbiór. Studium psychologiczno-filozoficzne u podstaw wspótczesnej matematyki. Częstochowa: Wydawnictwo Wyższej Szkoły Pedagogicznej w Częstochowie. 